\title{
OPEN Evolution of Old World Equus and origin of the zebra-ass clade
}

\author{
Omar Cirilli, ${ }^{1,2 凶}$, Luca Pandolfi ${ }^{2 凶}$, Lorenzo Rook ${ }^{2}$ \& Raymond L. Bernor ${ }^{3,4}$
}

Evolution of the genus Equus has been a matter of long debate with a multitude of hypotheses. Currently, there is no consensus on either the taxonomic content nor phylogeny of Equus. Some hypotheses segregate Equus species into three genera, Plesippus, Allohippus and Equus. Also, the evolutionary role of European Pleistocene Equus stenonis in the origin of the zebra-ass clade has been debated. Studies based on skull, mandible and dental morphology suggest an evolutionary relationship between North American Pliocene E. simplicidens and European and African Pleistocene Equus. In this contribution, we assess the validity of the genera Plesippus, Allohippus and Equus by cladistic analysis combined with morphological and morphometrical comparison of cranial anatomy. Our cladistic analysis, based on cranial and postcranial elements (30 taxa, 129 characters), supports the monophyly of Equus, denies the recognition of Plesippus and Allohippus and supports the derivation of Equus grevyi and members of the zebra-ass clade from European stenonine horses. We define the following evolutionary steps directly relevant to the phylogeny of extant zebras and asses: E. simplicidens-E. stenonis-E. koobiforensis-E. grevyi -zebra-ass clade. The North American Pliocene species Equus simplicidens represents the ancestral stock of Old World Pleistocene Equus and the zebra-ass clade. Our phylogenetic results uphold the most recent genomic outputs which indicate an age of 4.0-4.5 Ma for the origin and monophyly of Equus.

The Old World Equus Datum is a widely recognized biochronological event by geochronologists, correlative with the beginning of the Pleistocene, $2.58 \mathrm{Ma}^{1-22}$. It is traditionally considered a significant event in the evolution of Plio-Pleistocene Old World mammalian faunas, represented by the immigration of the Pliocene North American Equus simplicidens into Eurasia across the Beringia land bridge e $^{3-8-11,17,18,21-24}$. This intercontinental dispersal is correlated with strong paleoclimatic variation documented in the terrestrial and marine records, driven by the beginning of a major glaciation pulse in the northern hemisphere ${ }^{17,25}$ (Fig. 1).

In the last century, evolution of the genus Equus was actively debated by biologists and paleontologists alike proposing a multitude of hypotheses ${ }^{1-12}$. Although most of the authors consider the North American E. simplicidens as the possible ancestor of the genus Equus ${ }^{1-6,11,18,22}$, there is no current consensus on either the taxonomic content nor phylogeny of Equus. In fact, Equus' traditional taxonomy was upended when some investigators proposed segregating the genus into three genera ${ }^{7}$ : North American Pliocene Plesippus ${ }^{13}$ (type species E. simplicidens), Pleistocene Eurasian and African Allohippus ${ }^{14}$ (type species E. stenonis) older than $1 \mathrm{Ma}$, and previously recognized species of Equus less than $1 \mathrm{Ma}$ as being the sole members of the genus. The segregation into these three genera was based on cranial morphology and proportion ${ }^{7}$. Notably, some studies used ten metric characters to distinguish Plio-Pleistocene species and extant Equus ${ }^{2}$, whilst more recent studies used only a single character (size of the cranium, brain-box) to distinguish among Plesippus, Allohippus and Equus ${ }^{7}$. The morphology of the dentition and postcranial elements was never taken into account. The validity of North American Plesippus and the European Allohippus was supported by a recent morphological qualitative cladistic analysis ${ }^{12}$, whereas another cladistic study supported the hypothesis of E. simplicidens as possible common ancestor for species of the genus Equus ${ }^{20}$. During the last decades, the Chinese species Equus E. qingyangensis was included within the genus Plesippus (P. qingyangensis) ${ }^{26}$, whereas the Chinese species Equus sanmeniensis (Allohippus sanmeniensis) ${ }^{27}$, the European Early Pleistocene species Equus livenzovensis and Equus senezensis (Allohippus livenzovensis and Allohippus senezensis) ${ }^{27-29}$, and the African Early Pleistocene Equus koobiforensis (Allohippus koobiforensis) ${ }^{29}$ were assigned to the genus Allohippus. Furthermore, other authors ${ }^{27}$, regarded Allohippus as a subgenus of Plesippus for the European Early Pleistocene species Plesippus (Allohippus) livenzovensis and Plesippus (Allohippus) stenonis.

${ }^{1}$ Dottorato Regionale Pegaso in Scienze della Terra, Università di Pisa, Via S. Maria 53, 56126 Pisa, Italy. ${ }^{2}$ Dipartimento di Scienze della Terra, Paleo[Fab]Lab, Università degli Studi di Firenze, Via G. La Pira 4, 50121 Firenze, Italy. ${ }^{3}$ Laboratory of Evolutionary Biology, Department of Anatomy, College of Medicine, 520 W St. N.W, Washington, DC 20059, USA. Department of Anthropology, Human Origins Program, Smithsonian Institution, Washington, DC 20560, USA. ${ }^{凶}$ email: omar.cirilli@phd.unipi.it; luca.pandolfi@unifi.it 


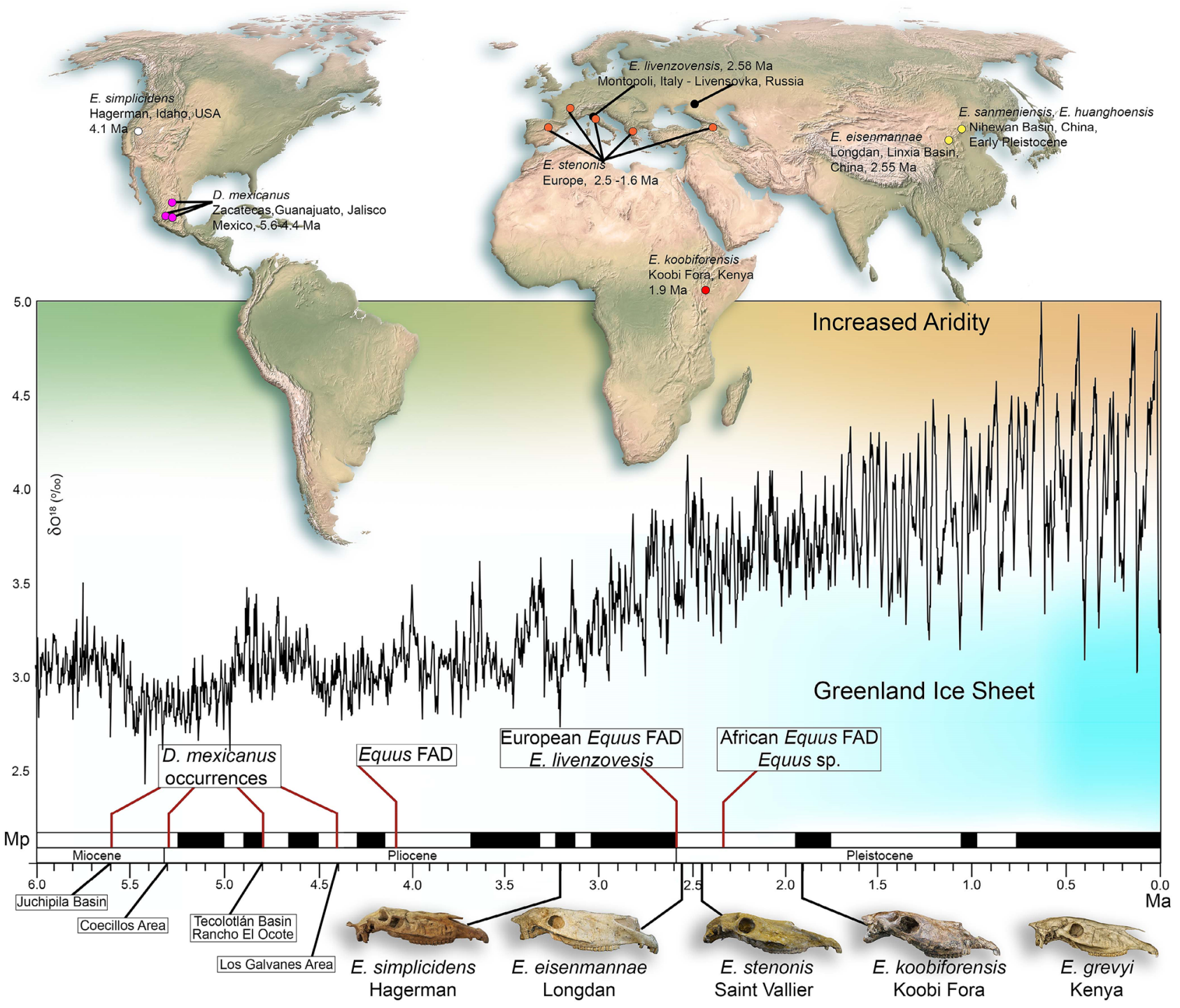

Figure 1. Geographic and age distribution of major events in the Old World Equus Evolution, including the Equus First Appearance Datum (FAD) in North America, $4.1 \mathrm{Ma}^{19}$, the Equus FAD in the Old World, $2.58 \mathrm{Ma}^{17-}$ 20,22 and the Equus FAD in Africa ${ }^{19}$. Dinohippus mexicanus localities are referred from recent studies ${ }^{21,34}$. The Old World Equus FAD at the base of the Pleistocene is correlated with the $\mathrm{O}^{18}$ isotopic global trend, marking a progressive environmental aridity since the beginning of the Pleistocene, within the paleoclimatic pulse recorded in terrestrial and marine strata, related to the initiation of a major glaciation pulse in the northern hemisphere ${ }^{17-19,22,30}$. Color points in map indicate the main occurrences of the selected Plio-Pleistocene fossil species (purple, Dinohippus mexicanus; white, Equus simplicidens; yellow, Chinese fossil species Equus eisenmannae, Equus sanmeniensis and Equus huanghoensis; black, Equus livenzovensis; orange, Equus stenonis; red, Equus koobiforensis). Map generated from row data of QGIS v.3.18.1 (https://www.qgis.org/it/site/) and edited by Adobe Photoshop CC2017. Abbreviations: Ma (age in million of years); Mp (Magnetic Polarity Time Scale); $\delta \mathrm{O}^{18}$ (Ratio of stable isotope oxygen-18 and oxygen-16).

Another controversial issue concerns European Pleistocene Equus stenonis role in the evolutionary history of Equus and the origin of the zebra-ass clade. Early studies ${ }^{2,15,16}$ suggested a relationship between Equus stenonis and extant Equus grevyi based on skull and dental morphology. A morphological similarity was further identified in the skull and dentition between E. stenonis, E. koobiforensis (Kenya, Africa, 1.9 Ma) and E. grevyi, suggesting that E. koobiforensis could be more closely related to European E. stenonis than the Chinese E. sanmeniensis ${ }^{2}$. Furthermore, some similarities were highlighted in skull, mandible and dental morphology between E. stenonis and E. simplicidens, suggesting that E. stenonis exhibits an intermediate morphology between the North American E. simplicidens and the African E. koobiforensis ${ }^{2}$. Nevertheless, other hypotheses ${ }^{3}$ identified E. stenonis as a branch of the E. simplicidens-E. sanmeniensis-E. koobiforensis-E. grevyi evolutionary lineage.

Herein, we assess the validity of the genera Plesippus, Allohippus and Equus by means of our cladistic analysis. We define the evolutionary relationships of E. stenonis to other Old World Pleistocene and extant Equus and the origin of the zebra-ass clade. 


\section{Results \\ Phylogenetic analysis. The cladistic analysis includes 30 Operative Taxonomic Units (OTU, with 4 out-} groups and 26 ingroups) and 129 characters and it has produced one most parsimonious tree (Fig. 2) (Tree Length $=398$ steps, Consistency Index $=0.472$, Retention Index $=0.705$; Homoplasy Index $=0.528$ ). The characters have been coded by direct observations on fossil collections combined with other published fossil specimens (see Methods below). The present phylogenetic tree clusters the family Equidae by node 57 with 13 unambiguous synapomorphies (Appendix 1) and, furthermore, the Miocene tridactyl genera Merychippus and Cormohipparion are segregated from the monodactyl genus Pliohippus by 6 unambiguous synapomorphies (Appendix 1). The species referred to the genera Merychippus, Hippidion and Dinohippus are clustered together as dichotomies, with Cormohipparion being sister to Merychippus.

The phylogenetic tree reveals outcomes for the Plio-Pleistocene species from North America and the Old World. Genus Equus is modeled as a single clade with node 52 being supported by 18 unambiguous synapomorphies, and 13 of these have a $\mathrm{CI} \geq 0.500$. The complete list is reported in Table 1 .

The bootstrap tree supports the Equus clade with 99/100 replications (Appendix 1, bootstrap tree and UPGMA tree). The species previously included within the genera Plesippus and Allohippus are not clustered from the Equus clade, identified by the node 52 (Fig. 2). This evidence is strongly supported by the bootstrap resampling analyses and tree, where the species included in the clade Equus are grouped as polytomies, except for 4 small clades (Appendix 1, bootstrap tree). These small clades cluster the North American species E. simplicidens with the Chinese E. qingyangensis (node 35; bootstrap values 95/100), the Equus sp. from Dmanisi (Georgia, Caucasus) with the fossil African E. oldowayensis (node 37; bootstrap values 77/100), the extant E. hemionus and E. kiang (node 44; bootstrap values 99/100) and E. przewalskii and E. ferus (node 44; bootstrap values 100/100). These subclades do not represent other genera in the Equus clade (node 52), but may indicate no relevant morphological difference between these species being scored with similar character states (Table S1). An analogous result was already highlighted in recent research applying Geometrics Morphometrics on cranial elements in extant species ${ }^{31}$.

Notably, E. simplicidens and E. qingyangensis differ only by a single character, the shape of palatine process (slender in the former and flat in the Chinese species), raising a question about the validity of E. qingyangensis. Another small clade including E. stenonis and E. senezensis in the parsimonious tree (node 36, Fig. 2) is not supported by the bootstrap resampling (Appendix 1).

Furthermore, the UPGMA tree based on the qualitative and quantitative characters described in the Table S1 may share new insights on the possible species relationships included in the Equus clade. The UPGMA well clusters the Equus clade from the other fossil genera of North and South America since the node 59 and, remarkably, separate the caballine horses (including E. przewalskii-E. ferus) from all other stenonine species (Appendix, UPGMA, node 58). This last cluster includes the entire fossil species from the New and the Old World and the extant zebras and asses. Noteworthy, the morphometric analyses based on the skull morphology show a similar result. The small clades within Equus evidenced by the most parsimonious tree and the bootstrap resampling are also present in the UPGMA tree (E. simplicidens-E. qingyangensis; Equus sp. Dmanisi-E. oldowayensis (Olorgesaile); E. hemionus-E. kiang; E. przewalskii-E. ferus) thus supporting their morphological similarities. The Early Pleistocene Chinese species E. eisenmannae is grouped with the E. simplicidens-E. qingyangensis clade, whereas, as reported in Fig. 2, E. livenzovensis and E. stenonis are the closest relatives of E. koobiforensis (Appendix 1, UPGMA tree). These relationships are reflected in the morphometric results on skulls, wherein E. koobiforensis is found to be closely related to E. sanmeniensis and E. stenonis (Fig. 3, S. text and Fig. S2). Equus sp. from Dmanisi (Equus aff. E. altidens ${ }^{35}$ ) and E. oldowayensis are still closely related ${ }^{11}$.

In our parsimonious tree (Fig. 2), E. quagga is regarded as a sister species of the E. hemionus-E. kiang clade. This result seems to be in contrast with the most recent molecular phylogenies ${ }^{32-34}$, wherein plain zebras and wild Asian asses are well clustered as distinct clades, indicting a remarkable difference in their genome sequences. Our outcomes may indicate a close morphological similarity in cranial and postcranial elements of the skeleton, which can be the results of multiple evolutionary or ecological factors and which will deserve future considerations and investigations.

Eventually, our analyses allow to support that the Plio-Pleistocene North American, Eurasian and African species can be all grouped within the genus Equus, and no distinction can be recognized for the genera Plesippus and Allohippus.

Morphometric analysis. PCA results are based on total (basal and lateral) selected measurements (Fig. 3a,b), and basal measurements of the skull (Fig. 3c,d; see S. text for skull measurement references). Considering basal and lateral skull measurements (Fig. 3a), PC1 and PC2 accounts for most of the variance with $71.3 \%$ $(\mathrm{PC} 1=54.0 \%$ and PC2 $=17.3 \%)$. The loadings' distribution is shown in Figure S3 and reported in Table S2. PC1 separates species by maximum length (M6 and M23) from negative to positive values (more to less elongated), whereas PC2 mostly clusters species by M3 and M31 in positive values, and M4 and M5 negative values. The opposite development of the vomerine length (M3) and post vomerine length (M4) shown in the PCA is given also in the Log10 Ratio diagrams outcomes (Figure S2): even if E. simplicidens, E. stenonis and E. grevyi show the same skull length, E. simplicidens is separated from E. stenonis and E. grevyi by its greatly elongated vomerine length (M3) and a reduced post vomerine length (M4), whereas E. stenonis and E. grevyi show a longer development of the post vomerine length (M4) and a reduced vomerine length (M3). M30 and M31 cluster E. simplicidens and E. stenonis, with E. grevyi which occupies an intermediate morphospace between these species. This evidence is supported also by the Log10 Ratio diagrams (Figure S2), with E. grevyi showing a skull basal morphology similar to E. stenonis, and the lateral, naso-incisival notch, and cheek tooth length being similar to $E$. simplicidens. The Old World Equus species exhibit a longer naso-incisival notch dimension when compared to $E$. 


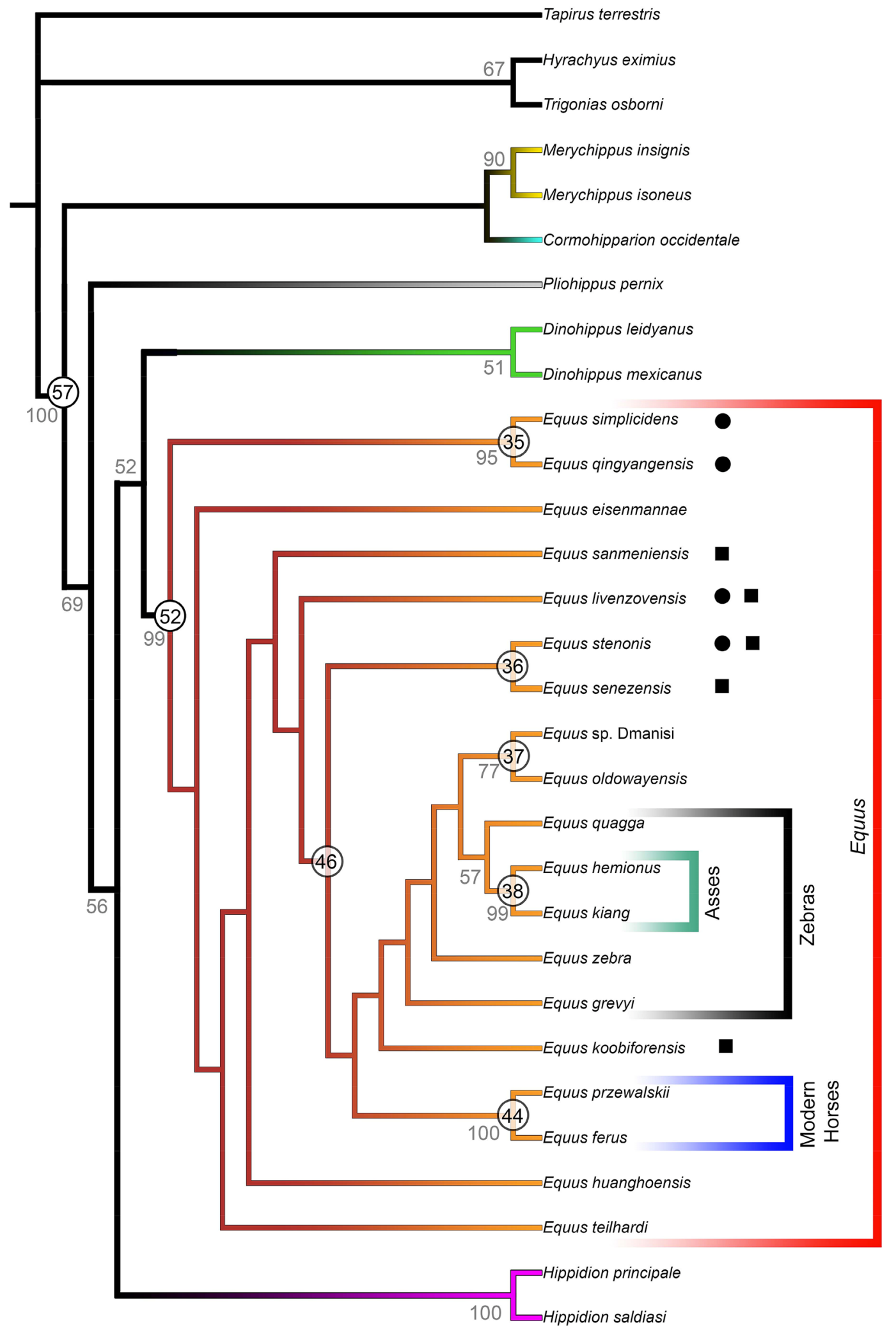

Figure 2. Most parsimonious tree of the cladistic analysis (30 taxa; 129 characters; Length $=398 ; \mathrm{CI}=0.472$; $\mathrm{RI}=0.705 ; \mathrm{HI}=0.528$ ) recovered by PAUP $4.0 \beta 10^{47}$ and edited by Adobe Photoshop CC2017. Grey numbers report the Bootstrap values, whereas numbers included in circles represent the nodes discussed in the text. Terminal color branches indicate the following different genera identified by the cladistic analysis: yellow, Merychippus; Cyan, Cormohipparion; grey, Pliohippus; purple, Hippidion; green, Dinohippus; dark red to orange, Equus. On the right, red color box indicates the genus Equus, black box Zebras, dark green box Asses and blue box Modern Horses. Black circles indicate the previous genus attribution to Plesippus, whereas black squares Allohippus. The detailed analyses are reported in Appendix 1. 


\begin{tabular}{|c|c|c|c|c|}
\hline Character description & Character number & Character state & Character state description & Consistency Index \\
\hline Length of the skull & 1 & 3 & Between 500 and $550 \mathrm{~mm}$ & 0.385 \\
\hline Lateral outline of skull & 2 & 0 & Linear & 0.500 \\
\hline Buccinator fossa & 16 & 1 & Absent or poorly developed & 1.0 \\
\hline Orbits position related to the upper third molar & 27 & 3 & Well behind the upper third molar & 0.375 \\
\hline Lingual margin of the protocone & 55 & 2 & Shallow depression on its medial aspect & 0.500 \\
\hline Protocone shape of the upper second premolar & 60 & 1 & Squared & 0.500 \\
\hline Hypocone shape of the upper third and fourth premolar & 61 & 1 & Squared & 0.167 \\
\hline Pli caballin shape of the upper third and fourth premolar & 62 & 2 & Present and elongated & 1.0 \\
\hline Protocone shape of the upper third and fourth premolar & 63 & 1 & Squared & 0.667 \\
\hline Hypocone shape of the upper first and second molar & 64 & 1 & Squared & 0.143 \\
\hline Upper premolar cheek teeth length & 71 & 2 & Between 100 and $110 \mathrm{~mm}$ & 0.375 \\
\hline Morphology of the metaconid-metastylid complex & 91 & 2 & V-shaped & 1.0 \\
\hline Morphology of the lingual side of the metastylid & 92 & 2 & Squared & 1.0 \\
\hline Functional morphology of foot & 114 & 2 & Hoof without soft pad, 3rd phalanx is strong and broad & 0.500 \\
\hline Elongation of the lateral second metacarpal & 116 & 3 & $\begin{array}{l}\text { Reduced up to the diaphysis and the proximal epiphysis } \\
\text { of the third metacarpal }\end{array}$ & 0.750 \\
\hline Elongation of the lateral fourth metacarpal & 118 & 3 & $\begin{array}{l}\text { Reduced up to the diaphysis and the proximal epiphysis } \\
\text { and the third metacarpal }\end{array}$ & 0.750 \\
\hline Elongation of the lateral second metatarsal & 122 & 3 & $\begin{array}{l}\text { Reduced up to the diaphysis and the proximal epiphysis } \\
\text { of the third metatarsal }\end{array}$ & 1.0 \\
\hline Elongation of the lateral fourth metatarsal & 124 & 3 & $\begin{array}{l}\text { Reduced up to the diaphysis and the proximal epiphysis } \\
\text { of the third metatarsal }\end{array}$ & 1.0 \\
\hline
\end{tabular}

Table 1. List of unambiguous synapomorphies of the Equus clade (node 52 in Fig. 2).

grevyi. Equus koobiforensis plots between E. stenonis, E. sanmeniensis and E. eisenmannae, even if the basal morphology of the skull appears to be more related to E. stenonis and E. sanmeniensis rather than E. eisenmannae. Nevertheless, its position in this diagram is influenced by the total maximum length (M6) and the upper cheek tooth row length (M7, M8, M9) which are slightly longer than E. stenonis and E. grevyi (see the original raw data in Table S3). The Chinese species E. eisenmannae and E. huanghoensis appear to be more closely related to $E$. simplicidens than E. stenonis. PC1 and PC3 account the $63.4 \%$ of the total variance $(\mathrm{PC} 1=54.0 \%$ and $\mathrm{PC} 3=9.4$, Fig. 3b; the loadings' distribution is shown in Figure S3b and reported in Table S2). PC1 separates species by M4 in positive values and maximum lengths (M6 and M23) in negative values (more to less elongated), whereas PC2 mostly clusters species by M5 and M31 with negative values (more to less elongated). In this diagram, $E$. simplicidens, E. stenonis and E. grevyi are closely clustered, overlapping some portions of their morphospaces. Equus koobiforensis plots between E. stenonis, E. sanmeniensis and E. eisenmannae, whereas E. huanghoensis is well separated from the entire sample by its reduced M5 and its elongated M2.

The PCA results on the basal skull measurements (Fig. 3c,d) do not include maximum skull length (M6). We have excluded this measurement in order to investigate the evolution of the basal skull morphology. PC1 and PC2 account for most of the variance with $74.7 \%$ (PC1 $=43.2 \%$ and PC $2=31.5 \%$, Fig. $3 \mathrm{c}$; the loadings distribution is shown in Figure S3c and it is reported in Table S2). PC1 separates species by M1 (ventral length of the muzzle) and M2 (palatal length), from negative to positive values (more to less elongated), whereas PC2 mostly clusters species by M3 in positive and M4-M5 in negative values. These results are congruent with the previous clustering pattern (Fig. 3a). Equus simplicidens and E. huanghoensis are clustered by their longer M3 length, whereas E. grevyi and E. stenonis show higher values for M4. Nevertheless, E. stenonis overlaps with $E$. grevyi's morphospace, providing additional support of the evidence shown in the Log10 Ratio diagram (Figure S2b). Equus koobiforensis is placed closer to E. stenonis and extant E. grevyi, whereas the Chinese species E. eisenmannae is the largest horse of the entire sample and E. sanmeniensis is placed between E. eisenmannae and E. stenonis. PC1 and PC3 account the $60.6 \%$ of the total variance $(\mathrm{PC} 1=43.2 \%$ and $\mathrm{PC} 3=17.4 \%$, Fig. $3 \mathrm{~d}$; the loadings' distribution is shown in Figure S3d and reported in Table S2). PC1 separates species by M4 with positive values and M1 and M3 with negative values (more to less elongated), whereas PC3 clusters species by M2 with positive values and M5 with negative values (more or less elongated). Equus stenonis and E. grevyi overlap extensively in their morphospaces which likewise include E. koobiforensis. Also, the E. simplicidens sample is placed close to E. stenonis, even if separated by the latter by its longer vomerine length (M3), and it includes $E$. sanmeniensis in its morphospace. Equus eisenmannae is more closely related to E. simplicidens than E. stenonis, supporting observations of the Log10 ratios diagrams (Figure S2a). Equus huanghoensis still remains separated from the entire sample by its reduced M5 and its elongated M2.

\section{Discussion}

Origin and early evolution of the Equus grevyi clade. Our phylogenetic and morphometric analyses, within the systematic position of Equus stenonis, provide novel insights into the phylogenetic relationships of the Old World Equus and the origin of the zebra-ass clade based on paleontological evidence (4,7, $11,12,15,18-22,36,37^{\text {. }}$ As reported in the outcomes shown by the morphometric analyses, the Early Pleistocene Chinese species E. 

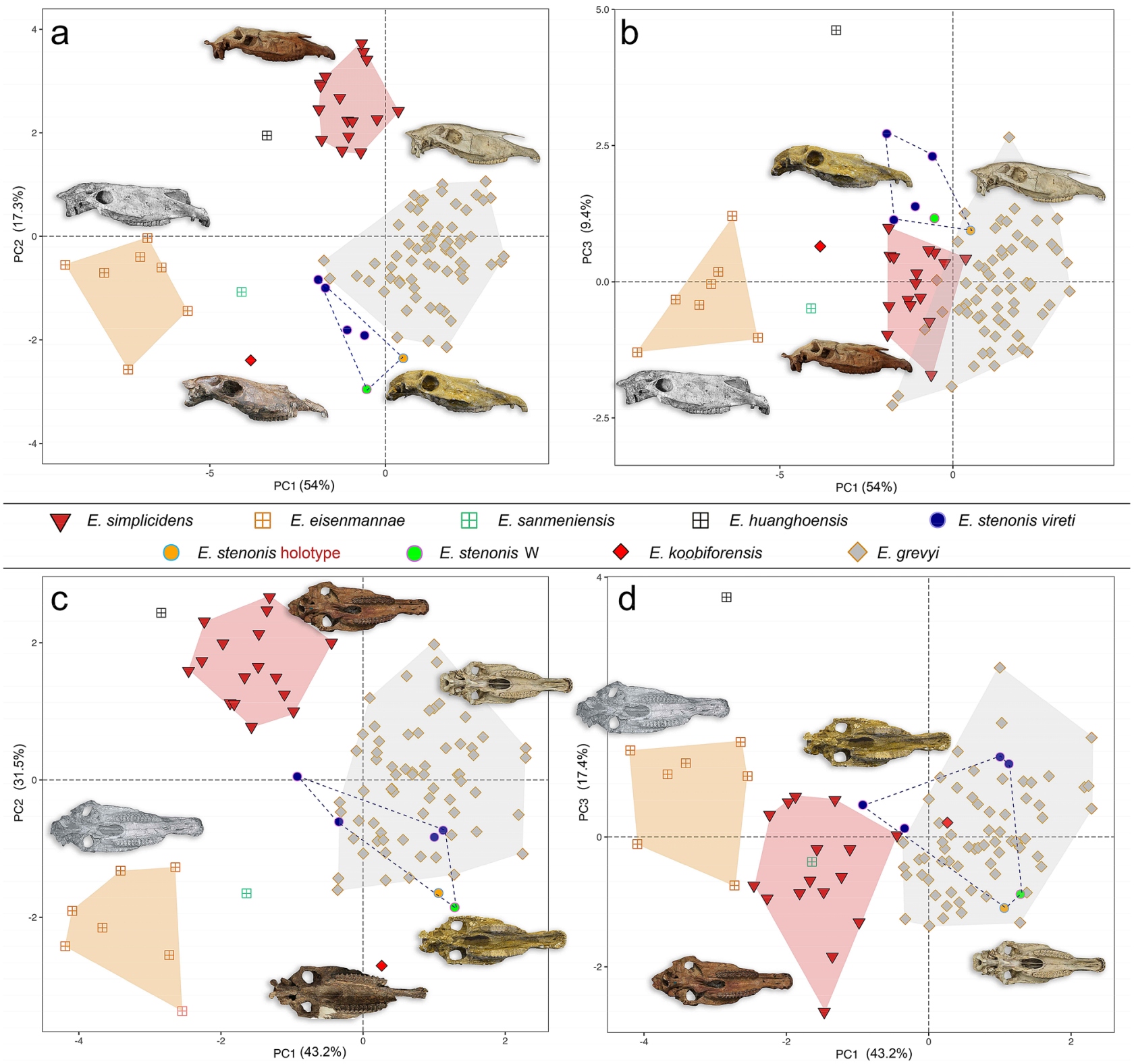

Figure 3. Results on PCA based on the selected skull measurements. Plots primarily obtained by R Studio Software v.1.4.103 $2020^{50}$ packages ggplot2() v.3.3.3 $3^{51}$ and $\operatorname{prcomp}()$ v.3.6.2 $2^{52}$. (a, b) show the PC1 versus PC2-PC3 outcomes on the skull basal and lateral measurements, whereas (c, d) show the PC1 versus PC2-PC3 results for the skull basal measurements. The analyses have been developed by the Software R using the packages $\operatorname{prcomp}()$ and ggplot2(). The original database is given in Table S3, whereas the loadings plots are shown in Figure S3.

eisenmannae, E. qingyangensis and E. huanghoensis have more primitive skull traits than E. stenonis that compare best with North American E. simplicidens, whereas the African E. koobiforensis and the extant E. grevyi are more closely related to E. stenonis and E. sanmeniensis. Nevertheless, Equus grevyi has a reduced muzzle when compared to the fossil species (Fig. 41). The E. simplicidens skull is characterized as having a longer vomer length and a reduced post vomerine length (Fig. 4a,c), whereas E. stenonis, E. koobiforensis and E. grevyi have a reduced vomer length and a longer post vomerine length (Figs. 4e,g,i,k). In lateral view, E. simplicidens (Fig. 4b,d) has an elongated skull with a linear dorsal outline and a deep incision of the narial notch, whereas the skulls of $E$. stenonis (Fig. 4f,h) and E. koobiforensis (Fig. 4j) have a concave dorsal skull outline, akin to E. grevyi (Fig. 4l).

Furthermore, this skull development could be related to the mandibular profile. Equus simplicidens has the mandibular ramus angled posteriorly, whereas that of $E$. stenonis is vertically oriented (Fig. $5 \mathrm{a}-\mathrm{d}$ ). There is no mandible associated with E. koobiforensis. Equus grevyi has a mandible shaped more like E. stenonis, with a steep vertical ramus and a large and round posterior angle of the mandible (Fig. $5 \mathrm{e}-\mathrm{f}$ ).

The preorbital fossa (POF) underwent progressive reduction in Equus species related to the increase in cheek tooth crown height ${ }^{7,11-14}$. Figure S4 summarizes POF evolution in E. simplicidens, E. eisenmannae, E. stenonis, E. koobiforensis and E. grevyi, in the lateral morphology of the skull by its perpendicular maximum height (M35), by distance between POF and the facial maxillary crest (M36) and by its height of the back of the POF above 

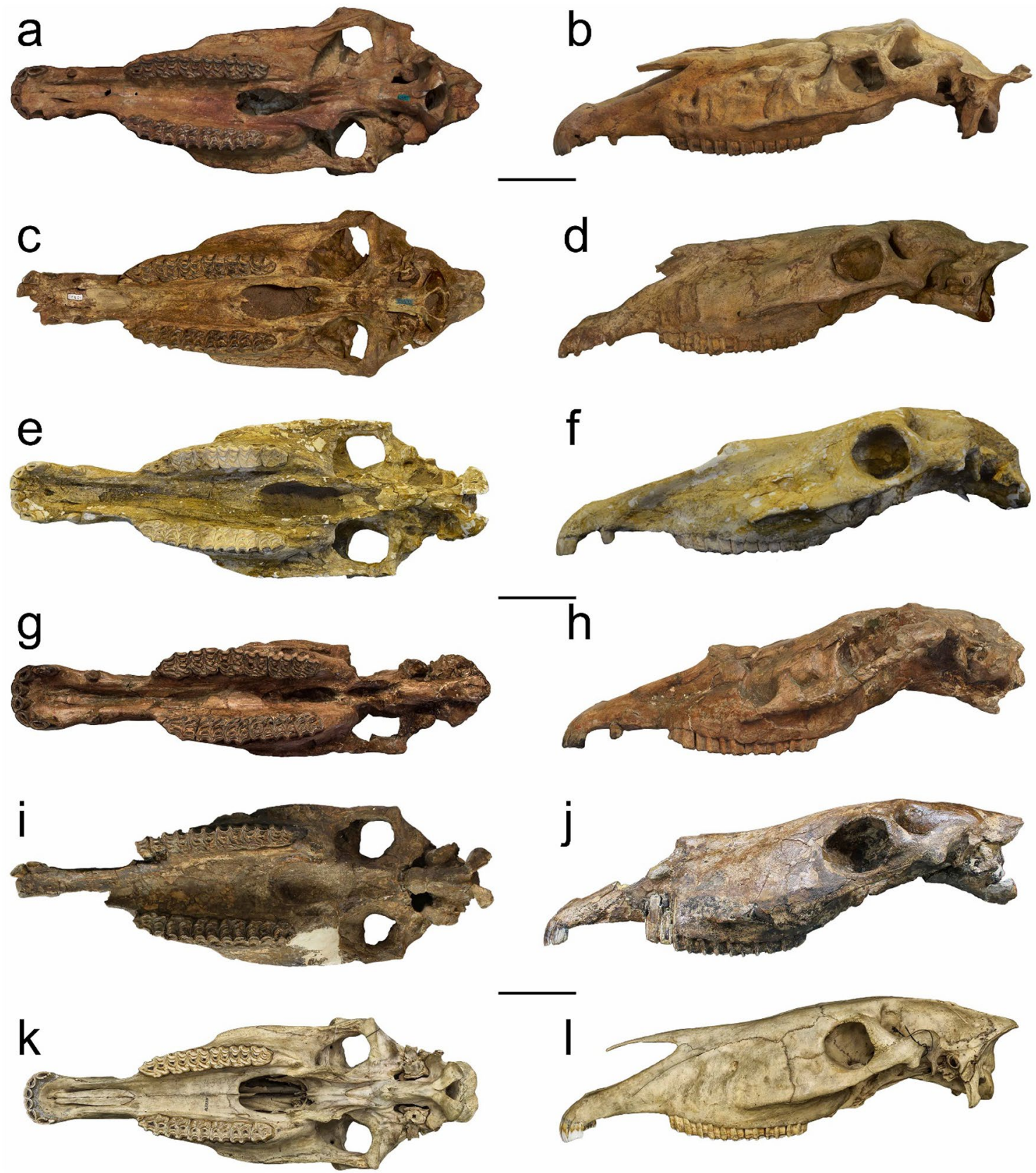

Figure 4. Comparisons of skulls, ventral and lateral views: E. simplicidens (USNM12573 and USNM12542, (a-d), E. stenonis (NHML20.163360 and IGF560 (e-h), E. koobiforensis (KNM-ER1284, i-j) and E. grevyi (USNM163228 k-l). Scale bar $10 \mathrm{~cm}$.

the alveolar border (M38). The POF is larger in E. simplicidens, E. eisenmannae and E. stenonis (M35) but it is placed higher on the maxilla (M36 and M38) in E. stenonis, E. koobiforensis and E. grevyi. Equus stenonis exhibits both plesiomorphic characters as does E. simplicidens and E. eisenmannae (M35), and more derived characters as seen in E. koobiforensis and E. grevyi (M36, M38) (S. text and Figure S4).

Recent research ${ }^{38,39}$ cites Equus' distinction as having the greatest crown height of all Equidae. In turn, increased hypsodonty is hypothesized to be an adaptation to more arid environments in the Early Pleistocene (a generalized Neogene trend in ungulates ${ }^{40}$ ). Horses became more adapted to grazing during the Pleistocene with a higher degree of hypsodonty and, as a consequence, increased hypsodonty also affected both the development of the lateral shape of the skull and the expression of the POF. Such evidence is provided by the evolution of the preorbital fossae (Fig. 3 and Figure S4), which is strongly reduced in E. grevyi and E. koobiforensis when compared to E. simplicidens.

Furthermore, there are important and consistent traits of the cheek tooth dentitions in Equus. The lingual margin of the protocone has a shallow depression on its medial aspect in E. simplicidens and E. stenonis, and it is more evident in E. koobiforensis and E. grevyi (S. text and Figure S5a-d; Ch. 55 in Table S1). In the lower cheek tooth row, the typical $\mathrm{V}$-shaped linguaflexid and stenonine metaconid-metastylid morphology is precociously 

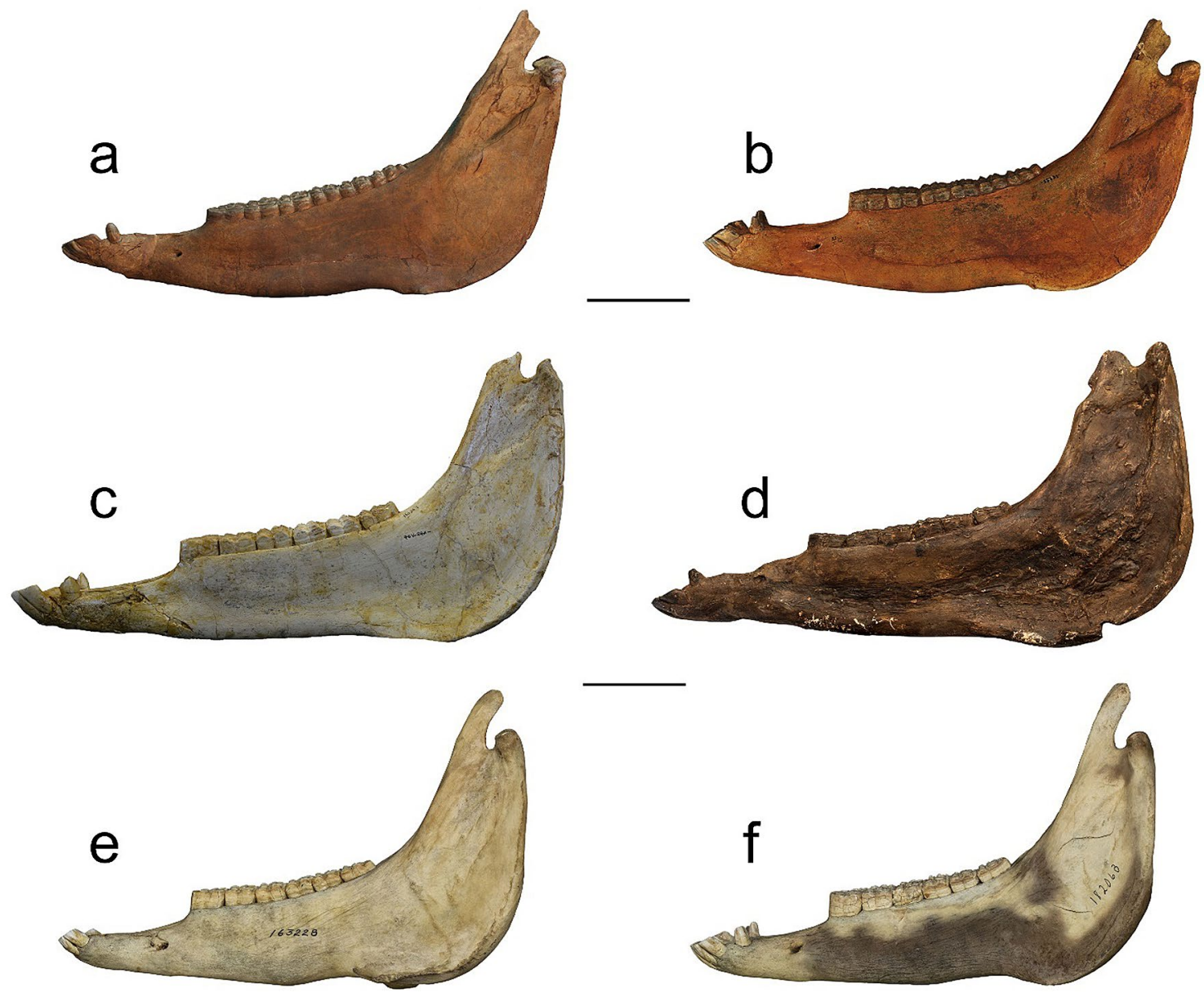

Figure 5. Mandible morphological comparison of E. simplicidens (USNM12573 and USNM12522, (a,b), E. stenonis (NHML20.163361 and IGF560, (c,d), and E. grevyi (USNM163228 and USNM182063 (e,f). Scale bar $10 \mathrm{~cm}$.

present in E. simplicidens (S. text and Figure S5f-h; Ch. 91 in Table S1). However, the remarkable squared morphology of the lingual margin of the metastylid is found in E. stenonis, E. koobiforensis and extant E. grevyi, and it is present, even if less clear, in E. simplicidens (S. text and Figure S5f-h; Ch. 92 in Table S1).

Evolutionary remarks. The various analyses provided herein have shown that the evolution of the head morphology occurred in the evolutionary steps E. simplicidens-E. stenonis-E. koobiforensis-E. grevyi + zebra-ass clade (Fig. 6) including: (i) the reduction of the vomerine length; (ii) elongation of the post vomerine length; (iii) reduction of the length of the naso-incisival notch; (iv) progressive reduction of the POF, from a large and more developed structure to a reduced and shallow morphology, which is still present in the extant zebras; (v) progressively more vertically oriented mandibular ramus; (vi) a more derived morphology of the lingual margin of the protocone; (vii) the advanced squared shape of the metastylid and persistent $\mathrm{V}$ - shaped linguaflexid .

Following Azzaroli and Voorhies ${ }^{5}$, we find that North American Pliocene Equus simplicidens represents the likely ancestral stock for the origin of Eurasian stenonine horses and ultimately African E. grevyi, and the zebra-ass clade ${ }^{1-6,9,11,18,41}$. Our phylogenetic results support Equus as being a single clade, with Dinohippus as the sister taxon. Our results do not support Plesippus and Allohippus at either the generic or subgeneric ranks. Our phylogenetic outcomes support the most recent genomic outputs ${ }^{9,33}$, which have found evolutionary rates for the Equus most common recent ancestor living 3.6-5.8 Ma. Ancient DNA analyses have shown slower mutation rates in horses than humans ${ }^{9}$ implying a minimal date of $4.07 \mathrm{Ma}$ for Equus' most common recent ancestor, proposing an age of 4.0-4.5 Ma for the origin of Equus. The concurrent evidence of our phylogenetic and the genomic results ${ }^{9}$ can be correlated with the most recent paleontological findings in Central America ${ }^{21,36}$, which have proved the occurrence of the primitive Equus morphologies ${ }^{36}$ at the Hemphillian-Blancan boundary at ca. $4 \mathrm{Ma}^{19,21,36}$ correlative with the onset of Pliocene global warming ${ }^{11,19,36,42}$.

\section{Methods}

Phylogenetic analysis. Our cladistic analysis uses 30 Operational Taxonomic Units (OTUs) and 129 characters (72 cranial, 40 mandibular and 17 on autopodia), including 26 equid taxa and 4 outgroups, Tapirus terrestris, Hyrachyus eximius, Trigonias osborni and Merychippus insignis (Appendix 1 and Table S1). The complete 


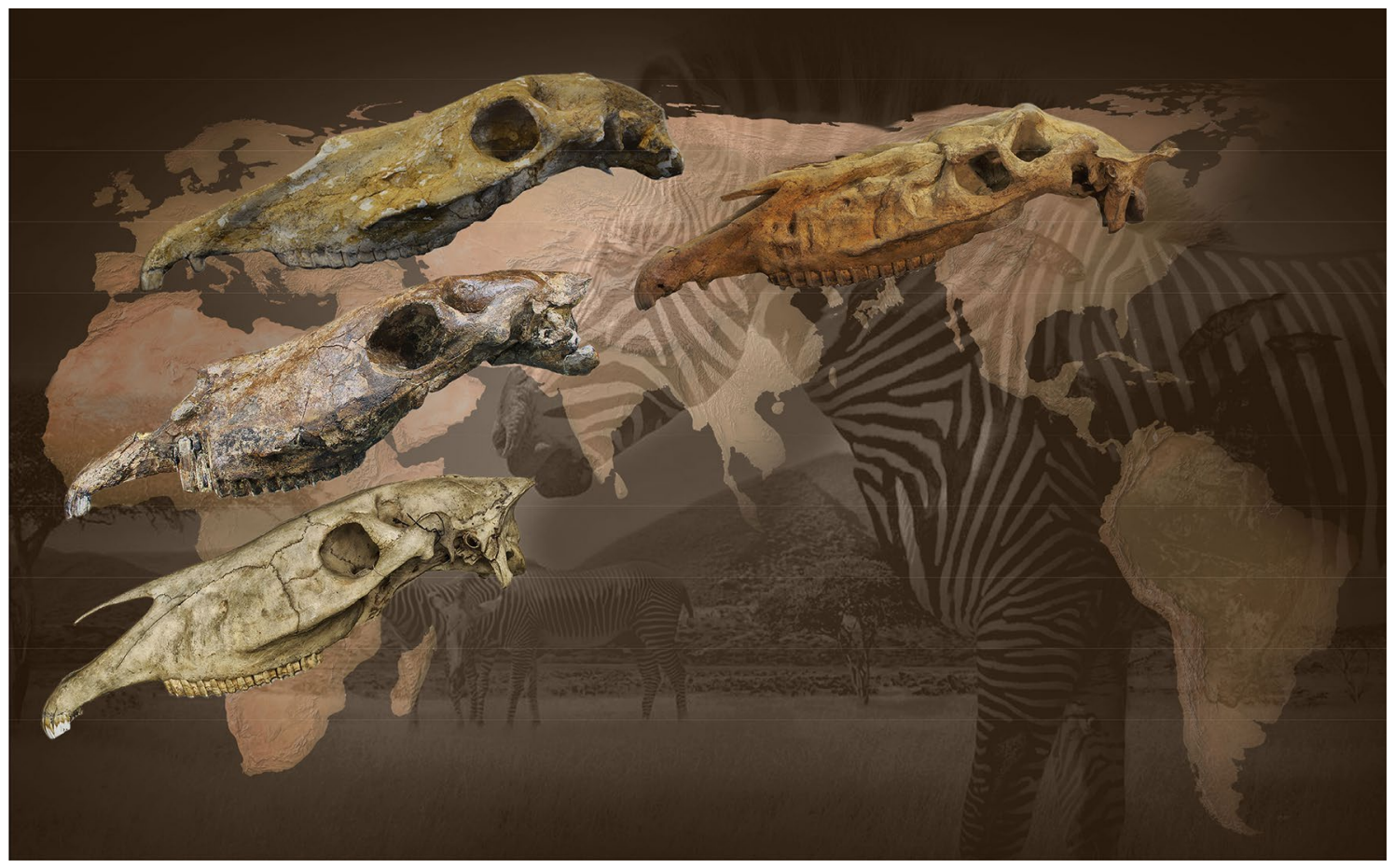

Figure 6. Evolutionary framework of the extant zebras Equus grevyi since the oldest common ancestor Equus simplicidens, and through the European Equus stenonis and the African Equus koobiforensis. The present figure aims to represent the dispersal of the genus Equus in the Old World by E. simplicidens at the beginning of the Pleistocene, and the origin of the extant zebras E. grevyi through the E. stenonis and E. koobiforensis lineage. Artwork O. Cirilli (map edited from row data of QGIS v.3.18.1 (https://www.qgis.org/it/site/), zebras in background edited from Nina Marie Photography (https://ninamarievisuals.com/)).

sample of the specimens coded in the cladistic matrix is reported in S. text. The matrix used in this cladistic analysis includes 68 novel characters, combined with the most recent matrices for equids and perissodactyl cladistic analyses ${ }^{12,20,43-46}$ (Table S1). The characters have been coded by direct observations. 24 characters are ordered $(2,5,9,10,11,12,13,14,16,22,23,42,43,52,78,91,92,113,114,116,118,121,123,129)$ and 105 characters unordered. All characters were equally weighted. The phylogenetic analysis was undertaken using PAUP $4.0 \beta 10^{47}$, under parsimony using Heuristic Search with the TBR (tree bisection reconnection) branch-swapping algorithm, 1000 bootstrap replications with additional random sequence, gaps treated as missing.

Morphometric analysis. We have undertaken statistical analyses (Log10 ratio diagrams, PCA, and boxplots) on selected skull, mandible and dental morphologies and measurements (S. text) to evaluate our cladistic analysis of Plio-Pleistocene Holarctic and African Equus evolution. We use international equid measurement standards ${ }^{48,49}$. Plots were generated primarily using the R Studio Software v.1.4.103 $2020^{50}$ packages ggplot2() v.3.3.3 and $\operatorname{prcomp}()$ v.3.6.2, using the function $\left(\operatorname{scale}=\mathrm{T}\right.$ ). Following previous analytical studies ${ }^{7}$, we have selected skull length measurements, avoiding medio-lateral deformation which would adversely influence our results. The complete database used in the Morphometric analyses is reported in Table S3, including personal and other published available data ${ }^{53}-{ }^{56}$.

Received: 7 February 2021; Accepted: 21 April 2021

Published online: 12 May 2021

\section{References}

1. Skinner, M. P. \& Hibbard, C. W. Early Pleistocene pre-glacial and glacial rocks and faunas of north-central Nebraska. Bull. Am. Mus. Nat. Hist. 148, 1-148 (1972).

2. Eisenmann, V. Les Chevaux (Equussensulato) fossiles et actuels: cranes et dents jugalessupérieures. Cahiers de Paléonotlogie 15, $1-186(1980)$.

3. Azzaroli, A. Ascent and decline of monodactyl equids: A case for prehistoric overkill. Ann ZoolFenn 28, 151-163 (1992).

4. Azzaroli, A. Phylogeny of the genus Equus L.. Palaeont. Ital. 84, 11-16 (2002).

5. Azzaroli, A. \& Voorhies, M. R. The Genus Equus in North America. The Blancan species. Palaeont. Ital. 80, 175-198 (1993)

6. Alberdi, M. T., Ortiz Jaureguizar, E. \& Prado, J. L. A quantitative review of European stenonoid horses. J. Paleontol. 72, 371-387 (1998). 
7. Eisenmann, V. \& Baylac, M. Extant and fossil Equus (Mammalia, Perissodactyla) skulls: a morphometric definition of the genus Equus. Zool. Scr. 29, 89-100 (2000).

8. MacFadden, B. J. Fossil horses-Evidence for evolution. Science 307, 1728-1730 (2005).

9. Orlando, L. et al. Recalibrating Equus evolution using the genome sequence of an early Middle Pleistocene horse. Nature 499, 74-78 (2013).

10. Palombo, M. R. \& Alberdi, M. T. Light and shadows in the evolution of South European stenonoid horses. Fossil Imprint 73, 115-140 (2017).

11. Bernor, R. L. et al. Evolution of early Equus in Italy, Georgia, the Indian Subcontinent, East Africa, and the origins of African zebras. Front. Ecol. Evol. 7, 166. https://doi.org/10.3389/fevo.2019.00166 (2019).

12. Barrón-Ortiz, C. I. et al. What is Equus? Reconciling taxonomy and phylogenetic analyses. Front. Ecol. Evol. 7, 343. https://doi. org/10.3389/fevo.2019.00343 (2019)

13. Gazin, C. L. A study of the fossil horses remains from the Upper Pliocene of Idaho. Proc. U.S. Natl. Mus. 83, 281-320 (1936).

14. Gromova, I. V. Istorijaloshadej (rodaEquus) v StaromSvete. Chast' 2. Evoljutsijaiklassifikatsijaroda. Trudy PaleontologicheskogoInstitutaAkademiiNauk SSSR 17, 2 (1949).

15. Azzaroli, A. The two Villafranchian horses of the Upper Valdarno. Palaeontogr. Ital. 61, 1-15 (1964).

16. Eisenmann, V. Family Equidae. In Koobi Fora Research Project; Volume 2. The Fossil Ungulates: Proboscidea, Perissodactyla, and Suidae (ed. Harris, J. M.) 156-214 (Clarendon Press, 1983).

17. Lindsay, E. H., Opdyke, N. D. \& Johnson, N. M. Pliocene dispersal of the horse Equus and late Cenozoic mammal dispersal events. Nature 287, 135-138 (1980).

18. Bernor, R. L., Cirilli, O., Wang, S. Q. \& Rook, L. Equus cf. livenzovenzis from Montopoli, Italy (early Pleistocene; MN16b; ca. 2.6 Ma). Boll. Soc. Paleontol. Ital. 57, 203-216 (2018).

19. Rook, L. et al. Mammal biochronology (Land Mammal Ages) around the world from the late Miocene to middle Pleistocene and major events in horse evolutionary history. Front. Ecol. Evol. 7, 278. https://doi.org/10.3389/fevo.2019.00278 (2019).

20. Sun, B. \& Deng, T. The Equus datum and the early radiation of Equus in China. Front Ecol Evol 7, 429. https://doi.org/10.3389/ fevo.2019.00429 (2019).

21. Carranza-Castañeda, O. Dinohippus mexicanus (early-late, late, and latest Hemphillian) and the transition to genus Equus, in Central Mexico faunas. Front. Earth Sci. 7, 89. https://doi.org/10.3389/feart.2019.00089 (2019).

22. Cirilli, O., Bernor, R. L. \& Rook, L. New insights on the Early Pleistocene equids from Roca-Neyra (France, Central Europe); implications for the Hipparion LAD and the Equus FAD in Europe. J. Paleontol. https://doi.org/10.1017/jpa.2020.99 (2020).

23. Flynn, L. J., Tedford, R. H. \& Qiu, Z. Enrichment and stability in the Pliocene mammalian fauna of North China. Paleobiology 17, 246-265 (1991).

24. Vislobokova, I., Sotnikova, M. \& Dodonov, A. Bio-events and diversity of the Late Miocene-Pliocene mammal faunas of Russia and adjacent areas. In Distribution and Migration of Tertiary Mammals in Eurasia. A Volume in Honor of Hans De Brujin (eds Reumer, J. W. F. \& Wessels, W.) 563-574 (2003).

25. Ryamo, M. E., Lisiecki, L. E. \& Nisancioglu, K. H. Plio-Pleistocene ice volume, Antarctic climate, and the global $\delta 18 \mathrm{O}$ record. Science 313, 492-495 (2006).

26. Eisenmann, V. \& Deng, T. Equus qingyangensis (Equidae, Perissodactyla) of the upper Pliocene of Bajiazui, China: Evidence for North American origin of an Old World lineage distinct from E. stenonis. Quaternaire 2, 113-122 (2005).

27. Samson, P. Les Equidés fossiles de Roumanie. Geol. Romana 16, 165-352 (1975).

28. Eisenmann, V. The Equids (Mammalia, Perissodactyla) of Saint-Vallier (Drome, France) and other Plio-Pleistocene European equids. Geobios 37, 279-305 (2004).

29. Eisenmann, V. Pliocene and Pleistocene Equids: Paleontology versus molecular biology. Cour. Forsch. Inst. Senckenerg 256, 71-89 (2006).

30. Zachos, J., Pagani, M., Sloan, L., Thomas, E. \& Billups, K. Trends, Rhythms, and aberrations in global climate Ma to present. Science 292, 686-693 (2001).

31. Heck, L., Wilson, L. A. B., Evin, A., Stange, M. \& Sanchez-Villagra, M. Shape variation and modularity of skull and teeth in domesticated horses and wild equids. Front. Zool 15, 14 (2018).

32. Olrando, L. et al. Revising the recent evolutionary history of equids using ancient DNA. Proc. Natl. Acad. Sci. USA 106, 2175421759 (2009).

33. Vilstrup, J. L. et al. Mitochondrial phylogenomics of modern and ancient equids. PLoS ONE 8(2), e55950 (2013).

34. Jónsson, H. et al. Speciation with gene flow in equids despite extensive chromosomal plasticity. Proc. Natl. Acad. Sci. USA 111, 18655-18660 (2014)

35. Vekua, A. Die Wirbeltierfauna des Villafranchium vin Dmanisi und ihre biostratigraphische Bedeutung. Jahrbuch des RömischGermanischen Zentralmuseums Mainz 42, 77-180 (1995).

36. MacFadden, B. J. \& Carranza-Castañeda, O. Cranium of Dinohippus mexicanus (Mammalia: Equidae) from the Early Pliocene (latest Hemphillian) of Central Mexico, and the origin of Equus. Bull. Florida Mus. Nat. Hist. 43, 163-185 (2002).

37. Cirilli, O., Pandolfi, L. \& Bernor, R. L. The Villafranchian perissodactyls of Italy: Knowledge of the fossil record and future research perspectives. Geobios 63, 1-21 (2020).

38. Mihlbachler, C., Rivals, F., Solounias, N. \& Semprebon, G. M. Dietary change and evolution of horses in North America. Science 331, 1178-1181 (2011).

39. Cantalapiedra, J. L., Prado, J. L., Hernandez Fernandez, M. \& Alberdi, M. T. Decoupled ecomorphological evolution and diversification in Neogene-Quaternary horses. Science 335, 627-630 (2017).

40. Jernvall, J. \& Fortelius, M. Common mammals drive the evolutionary increase of hypsodonty in the Neogene. Nature 417, 538-540 (2002).

41. McDonald, H. Population structure of the late Pliocene (Blancan) zebra Equus simplicidens (Perissodactyla: Equidae) from the Hagerman Horse Quarry, Idaho. In Paleoecology and Paleoenvironments of Late Cenozoic Mammals:Tributes to the Career of CS (Rufus) Churcher (eds Stewart, K. M. \& Seymour, K. L.) 134-155 (University of Toronto Press, 1996).

42. Burke, K. D. et al. Pliocene and Eocene provide best analogs for near-future climates. Proc. Natl. Acad. Sci. USA 115, 13288-13293 (2018).

43. Bennett, D. K. Stripes do not a zebra make, Part I: A cladistic analysis of Equus. Syst. Zool. 29, 272-287 (1980).

44. Antoine, P. O. Phylogénie et évolution des Elasmotheriina (Mammalia, Rhinocerotidae). Mémoir. Mus. Natl. Hist. 188, 1-359 (2002).

45. Antoine, P. O. et al. A revision of Aceratherium blanfordi Lydekker, 1884 (Mammalia: Rhinocerotidae) from the Early Miocene of Pakistan: postcranials as a key. Zool. J. Linn. Soc.-Lond. 160, 139-194 (2010).

46. Pandolfi, L. Persiatherium rodleri, gen. et sp. nov. (Mammalia, Rhinocerotidae), from the Late Miocene of Maragheh (Northwestern Iran). J VertPaleontol 36, e1040118. https://doi.org/10.1080/02724634.2015.1040118 (2015).

47. Swofford, D. L. PAUP* (Phylogenetic Analysis Using Parsimony [ ${ }^{*}$ and Other Methods] Version $4.0 \beta 10$ (Sinauer, 2001).

48. Eisenmann, V., Alberdi, M. T., De Giuli, C. \& Staesche, U. Methodology. In Studying fossil horses (eds Woodburne, M. \& Sondaar, P. Y.) 1-71 (Leiden, EJ Brill Press, 1988).

49. Bernor, R. L., Tobien, H., Hayek, L. A. C. \& Mittmann, H. W. Hippotherium primigenium (Equidae, Mammalia) from the late Miocene of Höwenegg (Hegau, Germany). Andrias 10, 1-230 (1997). 
50. R-Development Core Team R: A language and environment for statistical computing. R Foundation for Statistical Computing, Vienna, Austria. http://www.R-project.org/ (2020).

51. Wickham, H. ggplot2: Elegant Graphics for Data Analysis (ed. Wickham, H.) 1-260 (Springer, 2016).

52. Venables, W. N. \& Ripley, B. D. Modern Applied Statistics with S (ed. Venables, W. N. \& Ripley, B. D.) 1-498 (Springer, 2008).

53. Wang, S. Q. \& Deng, T. Some evolutionary trends of Equus eisenmannae (Mammalia, Perissodactyla) in the stratigraphic sequence of Longdan, China, in comparison to modern Equus. J Vert Paleontol 31, 1356-1365 (2011).

54. Li, Y., Zhang, Y., Sun, B., Ao, H. \& Xue, X. New fossils of the early Pleistocene Equus huanghoensis (Equidae, Perissodactyla) from Nihewan in Hebei province of China. Sci China Earth Sci 59, 83-94 (2016).

55. Cirilli, O. et al. Target deformation of the Equus stenonis holotype skull: A virtual reconstruction. Front Earth Sci 8, 247. https:// doi.org/10.3389/feart.2020.00247 (2020).

56. Eisenmann, V. Vera Eisenmann Website https://vera-eisenmann.com/ (2020).

\section{Acknowledgments}

We are grateful to several Institutions to provide us access to the collections. OC wishes to thank E. Cioppi and L. Bellucci (Museo di Storia Naturale dell'Univerisità degli Studi di Firenze, sezione di Geologia e Paleontologia), E. Robert (Université Claude Bernard - 1) and D. Berthet (Museé des Confluences) from Lyon, Amanda Millhouse and John Ososky (Museum Support Centre, National Museum of Natural History, Smithsonian Institution, Washington D.C., USA). OC thanks the financial support of the University of Pisa PhD program. LP developed this paper within the research project "Ecomorphology of fossil and extant Hippopotamids and Rhinocerotids" granted by the University of Florence ("Progetto Giovani Ricercatori Protagonisti" initiative).This contribution is framed within a wider project on late Neogene vertebrate evolution at the University of Florence (Fondi di Ateneo, to LR). RLB wishes to thank curators at the Smithsonian and AMNH museums of Natural History and acknowledges research funding by NSF EAR grants $8806645,0125009,1113175,1558586$ as well as DBI grant 1759882 for the FuTRES database, and support from the Smithsonian Human Origins Program. This is FuTRES publication number 22. The authors wish to acknowledge dr. C. Romagnoli for French advices. We thank all researchers who have shared her/his published data, allowing us to conceptualize and develop the present research. Eventually, the authors kindly acknowledge three anonymous reviewers which have improved the quality of the present work with their comments and suggestions.

\section{Author contributions}

O.C., L.P., L.R. and R.L.B. conceived the paper; O.C. and R.L.B. acquired data; O.C. developed the morphometric analyses; O.C., L.P. and R.L.B. developed the cladistic analysis; all authors discussed and interpreted the results and the equally contributed to finalize the manuscript.

\section{Competing interests}

The authors declare no competing interests.

Additional information

Supplementary Information The online version contains supplementary material available at https://doi.org/ 10.1038/s41598-021-89440-9.

Correspondence and requests for materials should be addressed to O.C. or L.P.

Reprints and permissions information is available at www.nature.com/reprints.

Publisher's note Springer Nature remains neutral with regard to jurisdictional claims in published maps and institutional affiliations.

(c) (i) Open Access This article is licensed under a Creative Commons Attribution 4.0 International License, which permits use, sharing, adaptation, distribution and reproduction in any medium or format, as long as you give appropriate credit to the original author(s) and the source, provide a link to the Creative Commons licence, and indicate if changes were made. The images or other third party material in this article are included in the article's Creative Commons licence, unless indicated otherwise in a credit line to the material. If material is not included in the article's Creative Commons licence and your intended use is not permitted by statutory regulation or exceeds the permitted use, you will need to obtain permission directly from the copyright holder. To view a copy of this licence, visit http://creativecommons.org/licenses/by/4.0/.

(c) The Author(s) 2021 